УДК 574.4

\title{
Potential of Biotechnology for Protecting Crops and Decreasing Yield Losses
}

\author{
Tatiana G. Volova* \\ Institute of Biophysics SB RAS \\ Federal Research Center \\ "Krasnoyarsk Science Center SB RAS" \\ 50/50 Akademgorodok, Krasnoyarsk, 660036, Russia \\ Siberian Federal University \\ 79 Svobodny, Krasnoyarsk, 660041, Russia
}

Received 27.02.2017, received in revised form 22.03.2017, accepted 23.03.2017

The study deals with problems of crop losses caused by pathogens, pests, and weeds and the global environmental problem of accumulation of protective chemicals in the biosphere. The author discusses potentials of biotechnology for plant protection and for decreasing the use of xenobiotics by replacing them with biofertilizers and biopesticides. Special attention is paid to the recent lines of research aimed at development and use of new-generation targeted and slow-release biotechnological preparations embedded in degradable matrix of microbial plastics - polyhydroxyalkanoates.

Keywords: crop protection, chemicals, biotechnology, biopesticides and biofertilizers, slow-release and targeted formulations, polyhydroxyalkanoates.

Citation: Volova T.G. Potential of biotechnology for protecting crops and decreasing yield losses. J. Sib. Fed. Univ. Biol., 2017, 10(2), 171-178. DOI: 10.17516/1997-1389-0020.

(C) Siberian Federal University. All rights reserved

* Corresponding author E-mail address: Volova45@mail.ru 


\title{
Потенциал биотехнологии
}

\section{для защиты культурных растений \\ и снижения потерь урожая}

\author{
Т.Г. Волова \\ Институт биофизики СО РАН \\ Федеральный исследовательский центр \\ «Красноярский научный чентр СО РАН» \\ Россия, 660036, Красноярск, Академгородок, 50/50 \\ Сибирский федеральный университет \\ Россия, 660041, Красноярск, пр. Свободный, 79
}

В работе обсуждаются проблемы, связанные с потерями в результате воздействия на культурные растения возбудителей болезней, вредителей и сорняков, а также с глобальной экологической проблемой аккумулящии в биосфере химических средств защиты. Рассмотрень перспективы биотехнологии для защиты растений и сокращения масштабов применения ксенобиотиков за счет применения биоудобрений и биопестицидов. Уделено особое внимание новейшим направлениям исследований, ориентированным на разработку и применение адресных и долговременных биотехнологических препаратов нового поколения, депонированных в разрушаемую основу из микробных биопластиков полигидроксиалканоатов.

Ключевые слова: защита культурных растений, химические препараты, биотехнология, биопестиииды и биоудобрения, долговременные и адресные препараты, полигидроксиалканоаты.

\section{Introduction}

The effectiveness of agricultural technologies in food production is determined by various factors, including ecological, geographical, and economic ones; it also depends on renewable biological resources such as crops, domestic animals, and microorganisms. Considerable research effort in various sciences has focused on increasing the biological production in agriculture. Modern intensive farming is impossible without pesticides. The global losses of potential yields caused by pests reach $37 \%$ : $13 \%$ of them are due to insects, $12 \%$ due to weeds, and $12 \%$ due to diseases. The annual losses are assessed at U.S. \$ 2000 billion (Oerke, 2006; Pimentel, 2009). However, pesticide build-up in the biosphere, via accumulation and concentration in food chains of biota in agroecosystems and natural ecosystems, poses global environmental threat (Hansen et al., 2004). Thus, only a small part of pesticides in the environment reach their goal; the remaining pesticides kill useful organisms, accumulate in biological objects, destroy the balance in natural ecosystems, and contaminate soil, water, and air. The scale of pesticide application is very large and keeps on growing; at the beginning of the $21^{\text {st }}$ century, the pesticide market approximated U.S. \$ 30 billion. Pesticides are chemical compounds of various classes, which are used for pest control in agriculture, medicine, industry, petroleum production, and other applications. Pesticides are mostly used in agriculture for controlling 
arthropods (insecticides and acaricides), nematodes (nematocides), fungal (fungicides) and bacterial (bactericides) diseases of animals and plants, as well as for weed control (herbicides). Pesticides are used as wettable aerosols, powders, emulsions, dusts, and granules. The "fate" of these compounds in the environment depends on the system of physical, chemical, and biological factors. The type of soil, its mineral and organic composition, moisture content, oxygen content, and temperature influence the rate of pesticide degradation, which is the result of oxidation, adsorption, hydrolysis, catalytic decomposition, processing by soil microorganisms. Unfortunately, wide application of pesticides failed to completely protect agricultural plants (Datta, Kaviraj, 2003). Very many insects and weeds are still uncontrolled and continue to cause damage to agriculture (Baligar, Kaliwal, 2003). Moreover, pests are beginning to develop resistance to pesticides. There are data showing that controlling some pests requires ultrahigh pesticide doses, which are thousand times greater than initial toxicant doses in the first years of application. Modern scientific literature contains descriptions of hundreds of species of arthropods resistant to various pesticides (DDT, carbamates, pyrethroids, organophosphorus compounds) (Popp et al., 2013). A number of pesticides with mutagenic and carcinogenic properties pose a threat to the health when getting into the organism with food, as they can cause neuropathy and dysfunction of endocrine system and affect reproductive function (Giri et al., 2002; Olgun et al., 2004). Pesticides are especially dangerous for infants in case of chronic intoxication of the child's organism by micro-doses of certain pesticides contained in food and household chemical goods (Weiss et al., 2004).

At the same time, the most intensive growth can be observed in consumption of pesticides belonging to new classes of compounds that have advantages over the previously used preparations and can solve the problems of pest and weed control more effectively. Since pesticides are important for agriculture, much research has been done to develop new formulations and investigate their behavior in the environment. Research is aimed at creation of pesticides with less toxic and more selective action and at decreasing their application rates. Thus, the wide use of products of chemical synthesis based on nonrenewable resources has led to an excessive and progressive increase in the amounts of unrecycled wastes, causing environmental concerns and posing a global environmental problem. A possible solution is the wider use of biotechnological tools and methods, which, on the one hand, protect useful biota and increase agricultural production and, on the other, decrease toxic impact on different ecosystems and the entire biosphere. An important scientific task is to provide a fundamental basis for construction and agricultural use of new-generation agrochemicals in order to decrease the risk from uncontrolled spreading and accumulation of chemical products of the technosphere in the biosphere.

\section{Modern approaches to plant protection and reduction of losses in agriculture}

It is particularly important to develop pesticide formulations for protecting cereals and potato - an essential crop used as food and feed and in technical applications. Potato yield losses may reach between 13 and $30 \%$. Therefore, studies aimed at developing effective formulations and technologies for controlling potato pests throughout the plant growing season have come to the fore. For measures aimed at protecting farm crops, including potato, to be effective, the methods and means used in every region must correspond to the climate, weather, and environmental conditions there. Thus, 
they should be thoroughly planned, taking into account all factors.

Pests, weeds, and pathogens can be controlled not only by chemicals but also by using crop rotation, killing weeds, especially wheat-grass as the main food for pests, frequently and thoroughly tilling the soil, and competently using fertilizers and chemicals affecting soil $\mathrm{pH}$. At the same time, environmentally safe agrotechnical measures, which reduce the damage done by wireworms to the minimum, have recently acquired increasing significance.

A promising approach to pest and plant pathogen control is development of biological crop protection (using beneficial organisms to control pests) combined with a system of protective measures: agrotechnical, quarantine, selection, and physiological ones (Agroecology, 2000). The use of microorganisms as biopesticides is a relatively new line of biotechnology, but it can boast considerable achievements. Bacteria, fungi, and viruses have been increasingly used as commercial biopesticides. The processes involved in production of these pesticides vary greatly, as producing microorganisms have diverse origins and physiological properties. However, all biopesticides must meet certain requirements such as selectivity and high efficacy, safety for people and useful plants and animals, long lifespans, ease of use, good wettability, and good adhesive properties. In addition to antibiotics, about 50 microbial formulations bacterial, fungal, and viral ones - are used now to protect plants and animals from insects and rodents. Integrated biological crop protection can extend the plant growing season by 2 weeks, increase cucumber and tomato yields to $5 \mathrm{~kg} / \mathrm{m}^{2}$, improve the sanitary conditions in greenhouses, enable production of health food, and lead to a $35 \%$ reduction in the cost of protective measures compared to pesticide use. Experts suggest that between 2014 and 2020, the world biopesticide market will develop at the fastest rate.

Over 90 bacterial species infecting insects have been described by now. They mainly belong to the families Pseudomonadaceae, Enterobacteriaceae, Lactobacillaceae, Micrococcaceae, and Bacillaceae. Most of the commercial strains are of the genus Bacillus, and more than $90 \%$ formulations are based on Bacillus thuringiensis (Bt), which has more than 22 serotypes. Bt-based formulations are intestinal toxins. Bacteria of the Bacillus thuringiensis group are effective against 400 insect species, including field, forest, orchard, and vineyard pests; these formulations are most effective against defoliators. More than $100 \mathrm{Bt}$ strains are united in 30 groups by their serological and biochemical characteristics. Microbiological industries in various countries produce different formulations based on Bt, which are capable of forming spores, crystals, and toxic substances while growing.

Promising contact biopesticides are fungal preparations. Numerous species of entomopathogenic fungi commonly occur in nature; they affect a wide range of insects through various mechanisms, including contact, which makes them convenient to use. Fungi produce various bioactive substances, which enhance their pathogenic effect. Fungal preparations, however, are not used widely now. First, certain technological difficulties are associated with cultivation of fungi, and, second, they can only be effective under limited environmental conditions (high and stable humidity). Hundreds of entomopathogenic fungi have been identified, but only two groups are regarded as very promising: muscardine fungi of the family Euascomycetes and entomophthoric fungi of the family Entomophthoraceae. Special consideration has been given to such pathogenic 
fungi as the causative agents of white muscardine disease (of the genus Beauveria) and green muscardine disease (of the genus Metarhizium) and Entomophthora, affecting sucking insects. Pathogenic fungi, unlike other microorganisms, are capable of infecting insects in different developmental stages (pupae or adults). Fungi grow quickly and have high reproductive capacity. For fungal preparations to be effective, they should be applied in a certain season and at optimal concentrations, as their development is determined by weather. This condition is a limitation to the wide use of fungal preparations in the form of spores. One way to enhance and keep physiological activity of fungal preparations in nature may be to immobilize the spores in polymeric carriers. Biological preparations are highly selective and safe for beneficial biota, higher animals, and humans. However, as it is difficult to produce them and their cost is too high, the scale of their application is limited, and they are mainly used outside Russia. In Russia, fungal preparations are in the research and development stage.

\section{Novel biotechnological approaches and formulations for protecting plants}

The newest trend in research is development and agricultural use of environmentally safe new-generation pesticides with targeted and controlled release of active ingredients embedded in biodegradable matrices or covered with biodegradable coatings, which are degraded in soil and other biological media by soil microflora to form products that are harmless to living and nonliving nature and which are gradually released into the environment. The use of such formulations can reduce the amounts of the chemicals added to the soil and enable their sustained and controlled delivery over a growing season, preventing sharp releases into the environment that occur in the case of using free chemicals. The crucial part of constructing such preparations is the availability of appropriate materials with the following properties: degradability, ecological compatibility with the environment and global biospheric cycles; safety for living and nonliving nature; long-term (weeks and months) presence in the natural environment and controlled degradation followed by formation of nontoxic products; chemical compatibility with pesticides and fertilizers; processability by available methods, compatible with pesticide and fertilizer production technologies.

Although traditional ways of pesticide use contradict the global effort to protect the environment and there is an urgent need to find more effective means and methods for plant protection, which will not adversely affect humans and nature, research aimed at development and use of environmentally safe and slow-release preparations still remains insufficient.

The starting point for the construction of slow-release formulations is the availability of a suitable biodegradable carrier. Thus, the search for and investigation of materials with the necessary properties is an important scientific task aimed at solving this problem. The materials extensively studied as matrices for embedding agricultural chemicals are synthetic nondegradable polymers (polystyrene, polyacrylamide, polyethylene acrylate, polyamide, polyurethane, polycyanoacrylate) (Pong et al., 2006). Studies published in recent years report investigations of degradable materials, which can be degraded by soil microflora; these materials do not pollute soil, and chemicals are gradually released from them. These are such materials as cellulose, agarose, dextran, carrageenan, starch, chitonases, alginates, protein-containing gelatin, and albumin (Asrar et al., 2004; Pong et al., 2006; Saravanan et al., 2008; Grillo et al., 2011; Kumar et al., 2014). The shortcoming of these natural 
polymers is their low mechanical strength and rapid hydrolysis in liquid media, which is an obstacle to preparing slow-release pesticide or fertilizer formulations.

Among biodegradable polymers, the most actively studied ones are polymers synthesized by bacteria in biotechnological processes polyhydroxyalkanoates (PHAs), which are thermoplastic, mechanically strong, and slowly degraded in biological media. As these polymers are disintegrated through true biological degradation and are not hydrolyzed in liquid media, products made of them can function in soil for months. The rates of release and delivery of the preparation can be regulated by controlling the degradation rate of the PHA matrix by using products of different shapes that contain different amounts of preparations. The first study of the possibility of pesticide encapsulation in PHA matrix was published by the authors (Voinova et al., 2009), and it reported encapsulation of hexachlorocyclohexane and lidane and kinetics of degradation of PHA matrix. The literature data on using PHAs to construct environmentally safe pesticide formulations are scant. Analysis of the available literature shows that research aimed at constructing such PHA-based formulation is only starting.

Pioneering studies that provided a scientific basis for using PHAs to develop new-generation formulations were performed by researchers of the Institute of Biophysics SB RAS. Implementation of the project "Fundamental basis for constructing and using new-generation agrochemicals" (No. 14-26-00039) resulted in development of the scientific foundation for the new line in ecological and agricultural biotechnology, including development of technologies for constructing new-generation slow-release formulations, construction and investigation of a series of fungicidal and herbicidal formulations and nitrogen fertilizers embedded in degradable polymer matrix (Boyandin et al., 2016; Volova et al., 2016a-d, 2017a, b).

The following results were obtained:

- the knowledge of conditions of interactions between chemicals and polyhydroxyalkanoates (PHAs) in different phase states and, based on this, development of methods of loading of the chemicals intended for suppressing agents of plant diseases and killing weeds and fertilizers into variously shaped polymer matrices;

- a series of experimental slow-release formulations produced using different methods; results of studying their structure and physical/mechanical properties;

- the knowledge of the release kinetics of the active ingredients from the polymer matrix obtained in laboratory soil microecosystems as dependent on the geometry of formulations, concentrations of the chemicals in them, chemical composition of the soil, and the type of soil microbial community;

- positive evaluation of the effectiveness of using the slow-release chemical formulations in laboratory conditions: in soil ecosystems with known properties containing higher plants infected by plant pathogens and weeds.

In the final stage of the project implementation, we studied the effectiveness of the formulations developed during the research in laboratory ecosystems with plants, which contained the following model weeds and crops:

- weeds (a perennial grass species Agrostis stolonifera - creeping bentgrass, Setaria macrocheata - foxtail millet, Chenopodium album - lamb's quarters, Melilotus albus - white sweet clover, Amaranthus retroflexus - red-root amaranth); 
- crops (lettuce Latuca sativa, wheat Triticum aestivum);

- soil microecosystems infected by plant pathogens Fusarium moniliforme and F. solani-root rot agents;

- crop Triticum aestivum infected by F. moniliforme and weeds.

The studies showed that the slow-release herbicide and fungicide formulations developed during implementation of this project were effective against weeds and plant pathogens and that their effects were comparable with or stronger than those of free forms of agrochemicals.

\section{Conclusions}

Positive results of the research project suggest that the use of natural polyesters, polyhydroxyalkanoates, as degradable polymer matrix for constructing slow-release formulations of agrochemicals is a useful approach and that the next step should be field tests of the experimental formulations. This study has produced new data on degradable PHAs as material for constructing slowrelease formulations of agrochemicals. The scientific basis has been provided for constructing environmentally friendly and targeted controlled-release formulations of fertilizers and pesticides to protect crops against pests and pathogens. The development of this line of research will help mitigate the risk of accumulation and uncontrolled spread of xenobiotics in the environment and replace dead-end synthetic plastics by degradable materials capable of joining the biospheric cycles.

\section{Acknowledgments}

The study was supported by the State budget allocated to the fundamental research at the Russian Academy of Sciences (project “№ AAAA-A17-117013050028-8) and IPSR Project "Development of new-generation slowrelease and targeted means for protecting potato".

\section{References}

Agroecology (2000) Chernikov V.A., Chekeres A.I. (eds.) Moscow, Kolos, 533 p. (in Russian)

Asrar J., Ding Y., La Monica R.E. (2004) Controlled release of tebuconazole from a polymer matrix microparticle: release kinetics and length of efficacy. J. Agric. Food Chem., 52: 4814-4820

Baligar P.N., Kaliwal B.B. (2003) Temporal effect of carbofuran, a carbamate insecticide in the interruption of estrous cycle and follicular toxicity in female Swiss albino mice. Bullet. Environ. Contam. Toxicol., 71 (3): 422-428

Boyandin A.N., Zhila N.O., Kiselev E.G., Volova T. (2016) Constructing slow-release formulations of metribuzin based on degradable poly(3-hydroxybutyrate). Journal of Agricultural and Food Chemistry, 64: 5625-5632

Datta M., Kaviraj A. (2003) Acute toxicity of the synthetic pyrethroid deltamethrin to freshwater catfish Clarias gariepinus. Bull. Environ. Contam. Toxicol., 70 (2): 296-299

Giri S., Prasad S.B., Giri A., Sharma G.D. (2002) Genotoxic effects of malathion: an organophosphorus insecticide, using three mammalian bioassays in vivo. Mutat. Res., 15: 223-231

Grillo R., Pereira A.E.S., Melo N.F.S. (2011) Controlled release system or ametryn using polymer microspheres: preparation, characterization and release kinetics in water. J. Hazard. Mater., 186: $1645-1651$

Hansen L.J., Schwacke L.H., Mitchum G.B., Hohn A.A., Wells R.S., Zolman E.S., Fair P.A. (2004) Geographic variation in polychorinated biphenyl and organochlorine pesticide concentrations in the 
blubber of bottlenose dolphins from the US Atlantic coast. Science of the Total Environment, 319 (1): $147-172$

Kumar S., Bhanjana G., Sharma A., Sidhu M.C., Dilbaghia N. (2014) Synthesis, characterization and on field evaluation of pesticide loaded sodium alginate nanoparticles. Carbohydr. Polym., 101: 1061-1067

Oerke E.C. (2006) Crop losses to pests. J. Agric. Sci., 144 (1): 31-43

Olgun S., Gogal R.M., Adeshina F., Choudhury H., Misra H.P. (2004) Pesticide mixtures potentiate the toxicity in murine thymocytes. Toxicology, 196: 181-195

Pimentel D. (2009) Pesticides and pest controls. Integrated pest management: innovation development process. Peshin R., Dhawan A.K. (eds.) Springer Science+Business Media, p. 83-87

Pong C., Kai L., Ming L., Chong H. (2006) Release properties on gelatin-gum arabic microcapsules containing camphor oil with added polystyrene. Colloids and Surfaces B: Biointerfaces, 50: 136-140

Popp J., Pető K., Nagy J. (2013) Pesticide productivity and food security. A review. Agron. Sustain. Dev., 33: 243-255

Saravanan M., Rao K.P. (2008) Pectin-gelatin and alginate-gelatin complex coacervation for controlled drug delivery: Influence of anionic polysaccharides and drugs being encapsulated on physicochemical properties of microcapsules. Carbohydr. Polym., 80: 808-816

Voinova O.N., Kalacheva G.S., Grodnitskaya I.D., Volova T.G. (2009) Microbial polymers as a degradable carrier for pesticide delivery. Applied Biochemistry and Microbiology, 45 (4): 384-388

Volova T.G., Zhila N.O., Prudnikova S.V., Shishatskaya E.I. (2016 a) Scientific basis for constructing new-generation agricultural preparations. Krasnoyarsk, 212 p. (in Russian)

Volova T.G., Zhila N.O., Vinogradova O.N., Nikolaeva E.D., Kiselev E.G., Shumilova A.A., Shershneva A.M., Shishatskaya E.I. (2016b) Constructing herbicide metribuzin sustained-release formulations based on the natural polymer poly-3-hydroxybutyrate as a degradable matrix. Journal of Environmental Science and Health, Part B, 51(2): 113-125

Volova T.G., Prudnikova S.V., Boyandin A.N. (2016 c) Biodegradable poly-3-hydroxybutyrate as a fertilizer carrier. Journal of the Science of Food and Agriculture, 96 (12): 4183-4193

Volova T., Zhila N., Vinogradova O., Shumilova A., Prudnikova S., Shishatskaya E. (2016d) Characterization of biodegradable poly-3-hydroxybutyrate films and pellets loaded with the fungicide tebuconazole. Environmental Science and Pollution Research, 23(6): 5243-5254

Volova T.G., Prudnikova S.V., Zhila N.O., Vinogradova O.N., Shumilova A.A., Nikolaeva E.D., Kiselev E.G., Shishatskaya E.I. (2017a) Efficacy of tebuconazole embedded in biodegradable poly-3-hydroxybutyrate to inhibit the development of Fusarium moniliforme in soil microecosystems. Pest Management Science, 73: 925-935

Volova T.G., Zhila N.O., Kiselev E.A., Prudnikova S.V., Vinogradova O., Nikolaeva E.D., Shumilova A.A., Shershneva A., Shishatskaya E.I. (2017b) Poly(3-hydroxybutyrate)/metribuzin formulations: characterization, controlled release properties, herbicidal activity and effect on soil microorganisms. Environmental Science and Pollution Research, 23: 23936-23950

Weiss B., Amler S., Amler R.W. (2004) Pesticides. Pediatrics, 113: 1030-1036 